\title{
Book Review: Nadine El-Enany B(ordering) Britain: Law, Race and Empire
}

Norman Ginsburg

First Published: 9 February 2021

https://0-doi-org.emu.londonmet.ac.uk/10.1177/0261018320960009a

This book examines British immigration policy through a radical, postcolonial, anti-racist lens. Its premise is that Britain is a white supremacist society and that British colonialism remains alive within law and policy as a 'racial regime of power' sustained by the traces of empire. It argues that 'racialized people' in Britain (and others wishing to migrate there) have (or should have) rights derived from the exploitation, injustices and terror of empire which entitle them to full 'citizenship'. Britain's wealth is built upon the spoils of empire, so colonised people and their descendants should have unfettered access to them. Hence 'recognition-based approaches to migrant solidarity', meaning efforts to secure forms of state recognition for individuals (including legal citizenship, refugee status, leave to remain etc) are misconstrued and diversionary. The author underlines the point that non-white people, even with legal citizenship, are less secure in their residency and rights, as demonstrated by, for example, aspects of the Windrush scandal, the Grenfell disaster, the 'hostile environment' policy, and the withdrawal of citizenship from those deemed to have terrorist links. Immigration policy 'orders' or divides British society into predominantly white legal citizens and predominantly nonwhite third-country nationals, migrant workers, refugees, asylum seekers and other precarious residents.

This lens is used to analyse some aspects of immigration legislation from the 1905 Aliens Act onwards. The author shows that the 1905 Act was not just about excluding Jewish people fleeing persecution in central Europe; its origins can be traced to the efforts of colonial governments in late nineteenth century Canada, Australia and South Africa to control the movement of non-whites by requiring them to have, for example, a certain amount of money and knowledge of a European language. This was the beginning of the emergence of an official national identity in the colonies and in Britain, which is white European, but not explicitly expressed as such. The core chapter then deals with the period from the 1948 to 1981 British Nationality Acts in which racialised immigration policy evolved as colonised people became no longer 'subjects' of the empire and found access to British citizenship increasingly denied to them. This is fairly well trodden ground for social scientists, but it has never been told in full, particularly the hostility of the 1945 Labour government to allowing access to non-white people 
from the colonies. In The Unwanted: The Secret Windrush Files, a June 2019 BBC documentary, David Olusoga revealed that Attlee described the arrival of people from the Caribbean as an 'incursion', amidst secretly expressed official fears that black immigrants would damage 'the harmony and cohesion of the nation'. These views could not be expressed publicly for fear of undermining Britain's economic and cultural ties with its soon to be former colonies, amidst the establishment of the Commonwealth. ElEnany maps out how governments managed the awkward transition to policy giving access to 'mother country' citizenship for descendants of white colonial settlers, while denying it to racialised former subjects of empire, including many already settled in Britain and their children. The long-term consequences were revealed when the 2014 Immigration Act introduced the 'hostile environment' measures to pursue unregularized 'migrants', leading to the withdrawal of basic rights from and even deportation of people with Caribbean heritage settled in Britain for decades - the Windrush scandal.

The chapter on more recent migrants and refugees brings the postcolonial lens to some interesting case examples, such as a woman from Tanzania who was a longestablished carer of a British woman. The Supreme Court decided in 2018 that she did not deserve consideration for permanent residence, despite the fact that she had clearly achieved a 'private and family life' as recognised by the European Convention on Human Rights as a basis for giving permanent residence rights. The author makes the point that non-white people are, of course, much more likely to have a precarious immigration status. Another case involved a woman from Uganda receiving effective treatment for HIVIAIDS in Britain who argued that her deportation would be tantamount to 'inhuman treatment' outlawed by the European Convention on Human Rights. The Supreme Court rejected this argument and she died three months after deportation. The majority decision was shaped by the concern that judgement in favour of this woman would open the 'floodgates' for others seeking treatment - it is access to what remains of the welfare state which has to be denied above all.

The discussion of these cases and of the role of law in this book hinges awkwardly on a paradox - individuals and their supporters struggle daily to achieve permanent and secure status, and access to the welfare state. This is a form of resistance to the structural and institutional racism embedded in policy. Yet that status should already be theirs, as the descendants of the colonised, and it is never an entirely secure status anyway. The reader is left with this paradox, which perhaps should be understood as a dialectic, which would give more analytical weight to the forces opposing white supremacism and the traces of empire in the British state and society. 